\title{
Optical, Structural and Electrical Properties of Electrochemical Synthesis of Thin Film of Polyaniline
}

\author{
Salah Abdulla Hasoon ${ }^{*}$
}

Received 28/11/2017

Accepted 7/2/2018
Sally Adel Abdul-Hadi ${ }^{2}$

\begin{abstract}
:
Polyaniline membranes of aniline were produced using an electrochemical method in a cell consisting of two poles. The effect of the vaccination was observed on the color of membranes of polyaniline, where analysis as of blue to olive green paints. The sanction of PANI was done by FT-IR and Raman techniques. The crystallinity of the models was studied by X-ray diffraction technique. The different electronic transitions of the PANI were determined by UV-VIS spectroscopy. The electrical conductivity of the manufactured samples was measured by using the four-probe technique at room temperature. Morphological studies have been determined by Atomic force microscopy (AFM). The structural studies have been measured by (SEM).
\end{abstract}

Keywords: Polyaniline, electrochemical methods, FT-IR, XRD studies, conducting Polymers.

\section{Introduction:}

The electrochemical manufacturing process is unique, and it is an exceptional way to manufacture polymers capable of conduction with the possibility of measuring the thickness and area of the product. Polyaniline (PANI) lodges the main place between the conducting classes of polymers. Polyaniline is odd phenyl built polymer own chemically elastic $\mathrm{NH}$-series in the polymer bounded via phenyl loop on both side (1). It symbolizes a group of macromolecules which conductivity of electrical enables changes from an insulator for a conductor through the redox procedure. The electron conductivity of polyaniline in the formula of emeraldine depends on its protonation and growths by ten orders of magnitude as the degree of protonation is increased from 0 to $20 \%$ (2). Indeed, the summary of heteroatoms makes it possible to compensate for the lack of stability of the Polyacetylene in the presence of atmospheric conditions. Their physical and chemical properties make them particularly attractive, they have great electrical conductivity (3). The stability of the environment is good in oxygen (4). In attendance is too scope of work in the field of solar power $(5,6)$. Organic photovoltaic cells (7), gas sensors $(8,9$, 10), a solid electrolytic capacitor (11), electrochromic windows and displays, and packaging, polymeric batteries $(12,13)$.

${ }^{1,2}$ Department of Physics, College of Science for Women, University of Baghdad, Baghdad, Iraq

*Corresponding :salahabd55@yahoo.com in addition to electric chromic projectors (14). History from conjugated polymers began in the early 1970 s when the sulfur polynitride $[(-\mathrm{S}=\mathrm{N}-)$ $\mathrm{x}]$ at room temperature has conductivity close to that of metals. This remarkable property attracts the interest of many the searchers, and it has rapidly studied other compounds that may be similar properties.

\section{Structure of Polyaniline}

The protonation and deprotonating and various other physics -chemical properties of PANI can be said to be due to the presence of the -NH- group. PANI has included the most usually calculated as a characteristic fellow for the polymer conductive private for the following causes, easy production. It is the individual conductive polymer that has an electronic and electrical structure. Properties can reversibly be controlled together via oxidation and protons. It takes exciting electrochemical performance, it appearances environment stability, easiness of non-redox doping by protonic acids (15).

\section{Symmetry and Group Theory}

In order to determine the vibrational modes that can be observed experimentally, the Group theory lets calculating the number of modes of vibration of molecules, as well as their symmetry. By applying, operations of symmetry can obtain the representation reducible of the molecule. Its 
decomposition into irreducible representations provides the number and the symmetry of the normal modes of vibration, once the modes corresponding to rotations and translations. The public formula with regard to aniline and polyaniline is shown in Fig.1 (a, b)

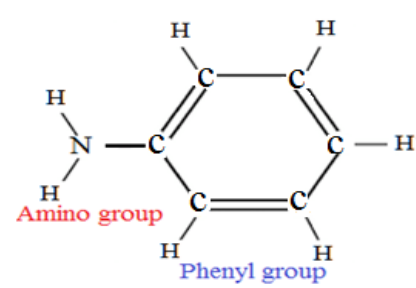

a

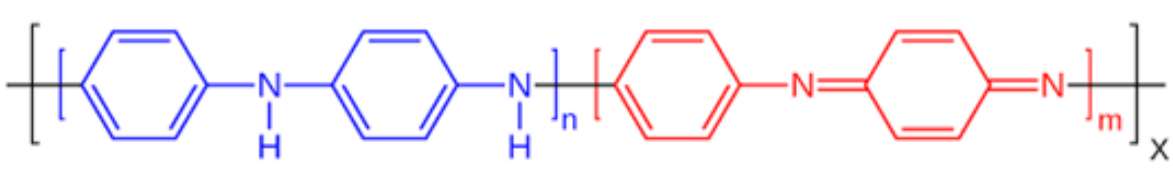

$\mathrm{b}$

Figure 1. a- public formulas concerning together aniline and the conductive b- polyaniline (emeraldine shape and there calculated structure).

The formula for aniline contains 14 atoms as shown in Fig. (a). application about group theory with monomer show $C_{2 v}$ similarity so will have 42 degrees of freedom, 6 of them are external vibrations, then will have 36 styles of hesitations, which are active together I.R and Raman as shown in Eq.1

$\Gamma_{\text {Vibration }=} 13 \mathrm{~A}_{1}+12 \mathrm{~A}_{2}+4 \mathrm{~B}_{1}+7 \mathrm{~B}_{2} \ldots .(1)$

By taking the monomer of bianiline with their radical as 4,4-diamine (Benzidine) structure, the group of symmetry for this structure will be $\mathrm{D}_{2 \mathrm{H}}$; hence own 78 non-reducible representations of Class 1 of the first Brillion region, the computations display that own 72 shapes of oscillation as shown in Eq. 2

$\Gamma_{\text {vibration }}=13 \mathrm{~A}_{\mathrm{g}}+4 \mathrm{~B}_{1 \mathrm{~g}}+12 \mathrm{~B}_{2 \mathrm{~g}}+7 \mathrm{~B}_{3 \mathrm{~g}}+5 \mathrm{~A}_{\mathrm{u}}+12 \mathrm{~B}_{1 \mathrm{u}}+12 \mathrm{~B}_{2}$ ${ }_{u}+7 B_{3 u}$

\section{Ring Vibrations:}

By taking the 4,4'-bianiline as shown in Fig. b without their radical we can suggest $\mathrm{C}_{2 \mathrm{~h}}$ point group, and exist have 36 irreducible representations and exist have 30 ring modes of vibrations as shown in Eq. 3

$\Gamma_{\text {vibration }}=11 \mathrm{~A}_{\mathrm{g}}+5 \mathrm{~A}_{\mathrm{u}}+4 \mathrm{~B}_{\mathrm{g}}+10 \mathrm{~B}_{\mathrm{u}} \ldots . .(3)$.

\section{Experimental:}

A quantity of $0.05,0.1$ and $0.2 \mathrm{M}$ aniline was added to $0.1 \mathrm{M}$ from electrolytic middle contained acetonitrile and Lithium tetrafluoroborate; they were located in a cell. Interaction was carried out inside the cell at a temperature of $0^{\circ} \mathrm{C}$. Thin films for polymer designed on the gold pole; however, other rod materials like ITO are as well apposite for that intent while the effort amount $>4 \mathrm{~V}$ the flow is gradually rising, The gold outward was thereafter shielded by means of a blue, strongly glued deposit; it's great accessibility that permitted a quick evolution on the membrane of numerous $\mu \mathrm{m}$ thickness. The color of the product was detected through the interaction; the blue was initially unclear and converted to blackish green while it was glutinous at the end of the interaction.

\section{Result and Discussion:}

\section{Infrared Spectroscopy (FT-IR)}

The structure of the produced PANI was described by Fourier Transform Infrared Spectroscopy (FTIR) and was able to obtain the spectra in the range of $(4000-400) \mathrm{cm}^{-1}$. FT-IR bands of PANI model prepared by $0.1 \mathrm{M}$ of aniline are shown in Fig. 2. In a spectrum, the bands detected at 3456,3421 and $3263 \mathrm{~cm}^{-1}$ is consequent at N-H stretching (16).The observed absorption bands of the polymer at 3066.82, 3028, 2974, 2931, 2862,2835 and $2021 \mathrm{~cm}^{-1}$ are due to irregular C-H stretching of the aromatic ring (17). The absorption points seen at $1635,1620,1554$ and $1504 \mathrm{~cm}^{-1}$ were credited to $\mathrm{C}=\mathrm{C}$ stretching in aromatic nuclei (1). The polymer appearances captivation bands at 1381, 1288 and $1230 \mathrm{~cm}^{-1}$ which form the C-N stretching of primary aromatic amines (18). The absorption bands centered at 1176, 1126 and 1091 $\mathrm{cm}^{-1}$ reveal the $\mathrm{C}-\mathrm{H}$ bending vibrations $(19,1)$.

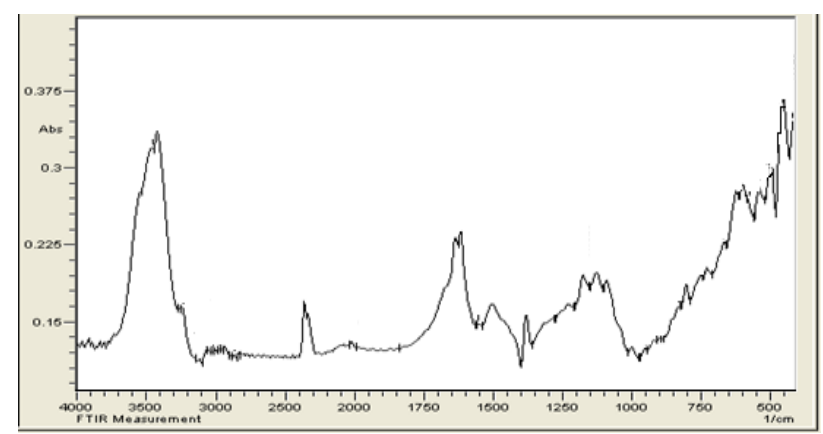

Figure 2. FTIR spectrum for thin films of polyaniline ready in $0.1 \mathrm{M}$ of aniline

Methods of calculation Ab-initio chemistry of quantum computation were performed in this paper for aniline by B3LYP/3-21G level, as were applied a semi-empirical Neglect of Differential Diatomic Overlap (MNDO) procedure in order to computing oscilloscope shapes, that is a lot faster than ab computation processes. The grounds series used in semi-experimental computational are particularly optimized minimum grounds series collected from Slater-type orbital's (20). Everything in computation 
processes was executed with the Hyperchem 8 bundle program. The computations values for wavenumber and intensity of the bands in Raman and I.R spectra were applied to explain the values of the experimentally gained of Raman and I.R ensembles. Some of these frequencies are given in Tables 1 and 2.

Table.1 Comparison of some experimental and theoretical harmonic frequencies in $\left(\mathrm{cm}^{-1}\right)$ from shapes in the infrared spectra of the nanopowder and thin membranes of polyaniline and the theoretical compatibility frequencies for bianiline and aniline in $\left(\mathrm{cm}^{-1}\right)$.

\begin{tabular}{|c|c|c|c|c|c|c|}
\hline $\begin{array}{l}\text { Bianiline } \\
\text { Ab- initio } \\
\text { small (3- } \\
21 G \text { ) only } \\
\text { IR active }\end{array}$ & (MNDO) & PANI expt ${ }^{a}$ & $\begin{array}{l}\text { Thin film } \\
\text { Monomer } \\
\text { concentration } \\
\text { 0.1M Prepared } \\
\text { with saline } \\
\text { solution } \\
\end{array}$ & $\begin{array}{c}\text { Thin film } \\
\text { Monomer } \\
\text { concentration } \\
\text { 0.2M Prepared } \\
\text { with saline } \\
\text { solution } \\
\end{array}$ & $\begin{array}{l}\text { Nano powder } \\
\text { Prepared with } \\
\text { acidic solution }\end{array}$ & Assignment \\
\hline 3731 & 3516 & $3428^{b}$ & 3456 & 3478 & 3464 & $v_{\mathrm{N}-\mathrm{H}}($ Ring 4$)$ \\
\hline 3611 & 3540 & $3352^{\mathrm{b}, \mathrm{c}, \mathrm{d}}$ & 3555 & 3560 & 3556 & $v_{\mathrm{N}-\mathrm{H}}(\operatorname{Ring} 3)$ \\
\hline 3326 & 3493 & & 3421 & 3417 & 3414 & $v_{\mathrm{C}-\mathrm{H}}(\operatorname{Ring} 1)$ \\
\hline 3290 & 3484 & & 34763336 & 3450 & 3440 & $v_{\mathrm{C}-\mathrm{H}}(\operatorname{Ring} 2)$ \\
\hline 3277 & 3487 & $3010^{\mathrm{e}, \mathrm{f}}$ & 3275 & & 3132 & $v_{\mathrm{C}-\mathrm{H}}(\operatorname{Ring} 3)$ \\
\hline \multirow[t]{3}{*}{3266} & 3487 & 3036 & 3236 & 3240 & 3240 & $v_{\mathrm{C}-\mathrm{H}}($ Ring 4$)$ \\
\hline & 3359 & 3096 & 3028 & 3024 & 3032 & $v_{\mathrm{C}-\mathrm{H}}(\operatorname{Ring} 1,2,3)$ \\
\hline & 3334 & 3071 & 3066 & 3055 & 3064 & $v_{\mathrm{C}-\mathrm{H}}(\operatorname{Ring} 1,2,3,4)$ \\
\hline 1881 & 1762 & $1500^{\mathrm{g}, \mathrm{h}}$ & 1680 & 1680 & - & $v_{\mathrm{C}=\mathrm{N}}(\operatorname{Ring} 1,2)$ \\
\hline 1854 & 1825 & & 1636 & 1636 & 1640 & $v_{\mathrm{C}=\mathrm{N}}(\operatorname{Ring} 1,2)$ \\
\hline 1820 & 1724 & & 1746 & 1746 & 1766 & $v_{\mathrm{C}-\mathrm{N}}(\operatorname{Ring} 3)$ \\
\hline 1650 & 1537 & & $1554 w$ & $1560 w$ & $1558 \mathrm{M}$ & $v_{\mathrm{C}-\mathrm{N}}(\operatorname{Ring} 1,2)$ \\
\hline 1551 & & & 1504 & 1496 & 1493 & $v_{\mathrm{C}-\mathrm{N}}(\operatorname{Ring} 3)$ \\
\hline 1576 & 1544 & $1294^{\mathrm{i}}$ & 1381 & 1381 & 1384 & $v_{\mathrm{C}-\mathrm{N}}(\operatorname{Ring} 1,2)$ \\
\hline 1512 & 1389 & $1415^{\mathrm{j}, \mathrm{k}}$ & 1314 & 1315 & 1296 & $v_{\mathrm{C}-\mathrm{N}}(\operatorname{Ring} 1)$ \\
\hline \multirow[t]{2}{*}{1426} & 1256 & $1293^{1}$ & 12301288 & 1230 & 1234 & $v_{\mathrm{C}-\mathrm{N}}(\operatorname{Ring} 4)$ \\
\hline & 723 & & 729 & 729 & 714 & $\gamma_{\mathrm{C}-\mathrm{N}}(\operatorname{Ring} 1,2,3,4)$ \\
\hline 1357 & 1262 & 1127,1153 & 1176 & 1176 & 1172 & $\delta_{\mathrm{C}-\mathrm{H}}(\operatorname{Ring} 4)$ \\
\hline \multirow[t]{2}{*}{1283} & 1230 & $1175,1312^{, \mathrm{c}, \mathrm{d}, \mathrm{g}, \mathrm{h}}$ & 1230 & 1238 & 1234 & $\delta_{\mathrm{C}-\mathrm{H}}(\operatorname{Ring} 1,2)$ \\
\hline & 779 & $995^{\mathrm{c}, \mathrm{d}}$ & 806 & 802 & 798 & $\gamma_{\mathrm{C}-\mathrm{H}}($ Ring 1$)$ \\
\hline 1172 & 1009 & $860^{\mathrm{m}}$ & 999 & $\approx 1003$ & 995 & $\gamma_{\mathrm{C}-\mathrm{H}}($ Ring2 $)$ \\
\hline \multirow[t]{3}{*}{832} & 955 & $902^{\mathrm{n}}$ & 952 & 956 & & $\gamma_{\mathrm{C}-\mathrm{H}}(\operatorname{Ring} 3)$ \\
\hline & 986 & $744^{\circ}$ & 898 & 848 & 837 & $\gamma_{\mathrm{C}-\mathrm{H}}($ Ring 4$)$ \\
\hline & 849 & & 1039 & 1045 & 1091 & $\delta_{\mathrm{N}-\mathrm{H}}(\operatorname{Ring} 3)$ \\
\hline \multirow[t]{2}{*}{743} & 431 & & 752 & 748 & 740 & $\gamma_{\mathrm{N}-\mathrm{H}}(\operatorname{Ring} 3)$ \\
\hline & 603 & & 806 & 802 & 798 & $\gamma_{\mathrm{N}-\mathrm{H}}(\operatorname{Ring} 4)$ \\
\hline \multirow[t]{2}{*}{1074} & 1050 & & 1091 & 1087 & absent & Breathing Ring1 \\
\hline & 1015 & & 1126 & 1130 & 1138 & $\begin{array}{l}\text { Breathing } \\
\text { Ring2,3,4 }\end{array}$ \\
\hline \multirow[t]{2}{*}{1023} & 1014 & & 1062 & 1065 & & $\begin{array}{l}\text { Breathing } \\
\text { Ring4,3,2 }\end{array}$ \\
\hline & 1632 & $1577^{\mathrm{i}}$ & 1620 & 1620 & 1616 & $v_{C=C}$ Ring 1 \\
\hline
\end{tabular}

${ }^{a}$ Experimental wave number $(18){ }^{b}$ Experimental wave number $(21){ }^{c}$ Experimental wave number (22)

${ }^{\mathrm{d}}$ Experimental wave number (23) ${ }^{\mathrm{e}}$ Experimental wave number (24) ${ }^{\mathrm{f}}$ Experimental wave number (25)

${ }^{\mathrm{g}}$ Experimental wave number (26) ${ }^{\mathrm{h}}$ Experimental wave number (27) ${ }^{\mathrm{I}}$ Experimental wave number (28)

${ }^{\mathrm{j}}$ Experimental wave number (29) ${ }^{\mathrm{k}}$ Experimental wave number (30) ${ }^{\mathrm{l}}$ Experimental wave number (31)

${ }^{\mathrm{m}}$ Experimental wave number (32) ${ }^{\mathrm{n}}$ Experimental wave number $(33)^{\mathrm{o}}$ Experimental wave number (34)

\section{Raman of Spectroscopy}

Fig. 3 shows the Raman of a spectrum of polyaniline. The incidence of the conducting PANI (emeraldine salt) was also sure of the most important band set at $1354 \mathrm{~cm}^{-1}$ corresponding to the $\mathrm{C}-\mathrm{N}$ bond. This so-called "protonation band". Characterizing the protonation state of the PANI is more intense in the PANI spectrum (35). The band at $1565 \mathrm{~cm}^{-1}$ has been gave to an in-plane bend the
C-C tie of the quinoid loop of the doped polyaniline. The stretching band at $1292 \mathrm{~cm}^{-1}$ is attributedto $\mathrm{C} \sim \mathrm{N}^{+\cdot}$ vibration of delocalized polarons in the extended polymenicchain. (36). A small number of the band was taken at $1063 \mathrm{~cm}^{-1}$ an inplane distortion of the $\mathrm{C}-\mathrm{C}$ chains of the quinoid ring from polyaniline. The band at $2185 \mathrm{~cm}^{-1}$ gave in $\mathrm{C}=\mathrm{C}-\mathrm{C}$ triple bond stretching. (37). 
Table 2. Comparison for some empirical oscillate numbers $\left(\mathrm{cm}^{-1}\right)$ from shapes in Raman spectra of the nanopowder and thin membranes of polyaniline and the theoretical compatibility frequencies for bianiline and aniline in $\mathrm{cm}^{-1}$.

\begin{tabular}{|c|c|c|c|c|}
\hline $\begin{array}{c}\text { Bianiline } \\
\mathrm{Ab} \text { initio/3-21G }\end{array}$ & PANI & PANI expt ${ }^{p}$ & Assignment & observed $\omega$ \\
\hline $\begin{array}{l}1844 \mathrm{Ag} \\
1682 \mathrm{Ag}\end{array}$ & $\begin{array}{l}1633^{q, \mathrm{r}} \\
1592^{\mathrm{q}, \mathrm{r}}\end{array}$ & $\begin{array}{l}1618^{p} \\
1578^{p}\end{array}$ & $\begin{array}{c}v_{\mathrm{C}=\mathrm{C}}(\mathrm{B} \text { ring }) \\
v_{\mathrm{C}=\mathrm{C}}(\mathrm{B} \& \mathrm{Q} \text { ring })\end{array}$ & 1635 or 1774 \\
\hline $1662 \mathrm{Ag}$ & $1604^{\mathrm{q}, \mathrm{r}}$ & $1615^{\mathrm{s}}$ & $v_{\mathrm{C}-\mathrm{C}}(\mathrm{B}$ ring $)$ & 1593 \\
\hline $1646 \mathrm{Ag}$ & $1472^{\mathrm{q}, \mathrm{r}}$ & $\begin{array}{l}1480^{\mathrm{s}} \\
1463^{\mathrm{t}}\end{array}$ & $v_{\mathrm{C}=\mathrm{N}}($ amine $)$ & 1480 \\
\hline $1533 \mathrm{Ag}$ & $1562^{\mathrm{q}, \mathrm{r}}$ & $1564^{\mathrm{u}}$ & $\delta_{\mathrm{N}-\mathrm{H}}(\mathrm{semi}-\mathrm{Q})$ & 1558 \\
\hline $1616 \mathrm{Ag}$ & $1220^{\mathrm{q}, \mathrm{r}}$ & $1220^{\mathrm{t}, \mathrm{u}}$ & $v_{\mathrm{C}-\mathrm{N}}($ amine $)$ & 1348 \\
\hline $1152 \mathrm{Ag}$ & $1166^{\mathrm{q}, \mathrm{r}}$ & $1163,1165 \mathrm{u}$ & $\delta_{\mathrm{C}-\mathrm{H}}(\mathrm{semi}-\mathrm{Q})$ & \\
\hline $1256 \mathrm{Ag}$ & & & $\delta_{\mathrm{N}-\mathrm{H}}$ & 1255 \\
\hline $1070 \mathrm{Ag}$ & $1074^{\mathrm{q}, \mathrm{r}}$ & 1076 & $\delta_{\mathrm{C}-\mathrm{H}}(\mathrm{B})$ & 1083 \\
\hline & $811^{q, r}$ & 815 & $\delta_{\mathrm{C}-\mathrm{C}}(\mathrm{BRing})$ & 816 \\
\hline $864 \mathrm{Ag}$ & & $997^{t}$ & Breathing & 1019 \\
\hline $750 \mathrm{Ag}$ & $785^{\mathrm{q}, \mathrm{r}}$ & $788^{t}$ & $\delta_{\text {Ring }}(\mathrm{Q}$ ring $)$ & 745 \\
\hline $683 \mathrm{Ag}$ & $743^{\mathrm{q}, \mathrm{r}}$ & $750^{t}$ & $\begin{array}{c}\delta_{\text {Ring }}(\text { imine and } \\
\text { amine })\end{array}$ & 676 \\
\hline $512 \mathrm{Ag}$ & $611^{\mathrm{q}, \mathrm{r}}$ & $632^{t}$ & $\delta_{\text {Ring }}(\mathrm{B}$ ring $)$ & 610 \\
\hline
\end{tabular}

${ }^{\mathrm{p}}$ Experimental wave number(38) ${ }^{\mathrm{q}}$ Experimental wave number (39) ${ }^{\mathrm{r}}$ Experimental wave number(40)

${ }^{\mathrm{s}}$ Experimental wave number (41) ${ }^{\mathrm{t}}$ Experimental wave number (42) ${ }^{\mathrm{u}}$ Experimental wave number $(43,44)$.

$\omega\left(\mathrm{cm}^{-1}\right)$ Symbols: B, benzenoid loop; Q, quinoid loop or benzene ring with quinoid Figure; $v$, dilation; $\delta$, in-plane curvature; $\gamma$, out of a level.

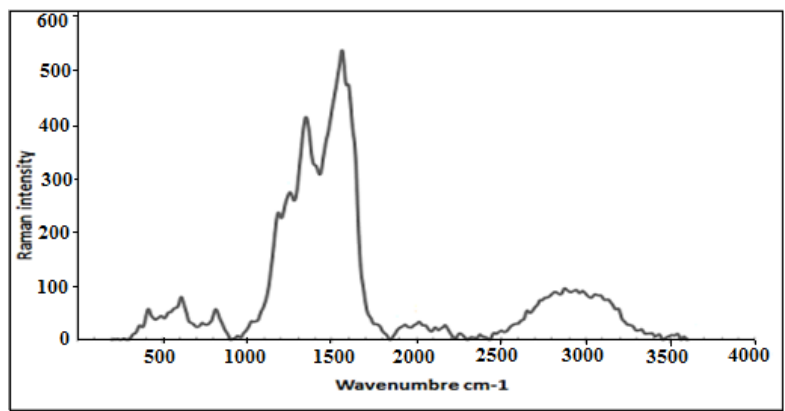

Figure 3. Raman spectrum of polyaniline thin films prepared by $0.1 \mathrm{M}$ of aniline. X-ray diffraction analysis

Fig.4 shows X-ray diffraction pattern of PANI thin film. XRD analysis of the prepared sample of thin film and nanopowder of polyaniline were diffracted meter system which records the intensity as a function of Bragg`s angle. Our Data was taken from the $2 \theta$ range of 10 to 80 degrees and listed in Table 3 .

Table .3 XRD analysis of PANI thin film.

\begin{tabular}{cccccccc}
\hline $\boldsymbol{2 \theta} \boldsymbol{1 5}$ & $15.5^{\circ}$ & $22^{\circ}$ & $26^{\circ}$ & $27^{\circ}$ & $30.7^{\circ}$ & $38^{\circ}$ & $4^{\circ}$ \\
\hline$(\boldsymbol{h} \boldsymbol{k})$ plane & 011 & 020 & 200 & 121 & 022 & 213 & 222
\end{tabular}

The intense bands observed at different angles of diffraction for a given pair of (hkl) values $2 \theta$ $\approx 11.5^{\circ}, 15.5^{\circ}(011), 22^{\circ}(020), 26^{\circ}(200), 27^{\circ}(121)$, $30.7^{\circ}(022), 38^{\circ}(213), 44^{\circ}(222), 65^{\circ}$, and $\sim 78^{\circ}$ confirm the synthesis of emeraldine salt of PANI.
Presence of distinguished peaks suggests the formation of highly crystalline and condensed structure of PANI thin films (45). The pattern appearances sharp and fine defined peaks, which show semi-crystalline nature of Polyaniline. The plains of Benzinoid and Quinoid rings of PANI chain are accountable for crystalline assembly(46). The average crystallite size (D) in $\AA$ was calculated by using Scherer's formula given by Eq. 4 .

$\{\mathrm{D}=[\mathrm{K} \lambda] /[\beta \operatorname{Cos} \theta]\} \ldots(4)$

Where $K$ is the shape factor usually has a value 0.94, $\lambda$ is the $\mathrm{X}$-ray wavelength and $\theta$ the Bragg angle and $\beta$ offers, the full width of the half maxima (FWHM). The determined average crystallite size was $32.45 \mathrm{~nm}$.

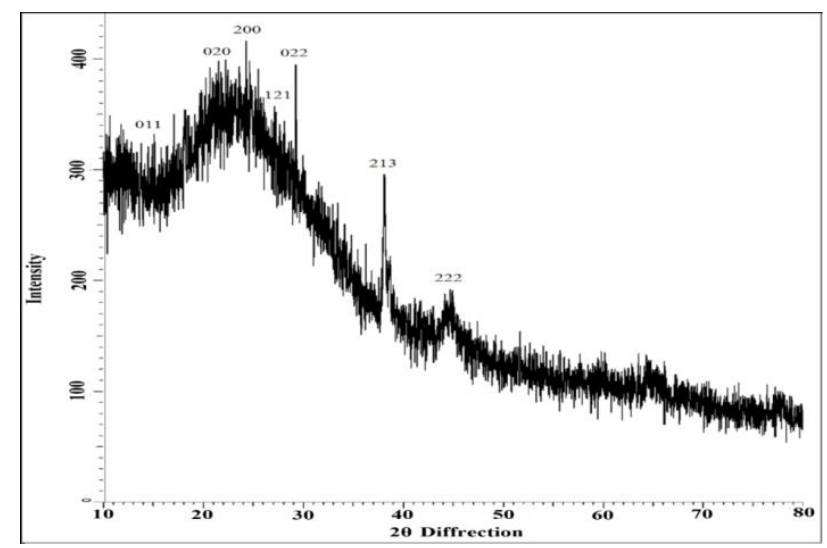

Figure 4. X-ray diffraction pattern of PANI thin films 


\section{UV-Vis Spectroscopy}

Fig .5 shows the absorbance as a function of the wavelength observed from the graph appearing two peaks. For absorption films (PANI), a note from the graph the appearance of two peaks of the absorption of the first peak appears at the wavelength $(361 \mathrm{~nm})$ indicating the transitions $\pi \rightarrow \pi^{*}(47)$. The second peak appears at a wavelength $(311 \mathrm{~nm})$ due to the transitions $\pi \rightarrow \pi^{*}$ as a result of the transition from the nitrogen oxide-containing non-atomic electrons to the conduction package. Reaching a peak of 361 $\mathrm{nm}$ into the level of doping and polaron formation (48). (protonation in PANI backbone, polaron/ bipolaron transition that occurred in doped PANI) (49).

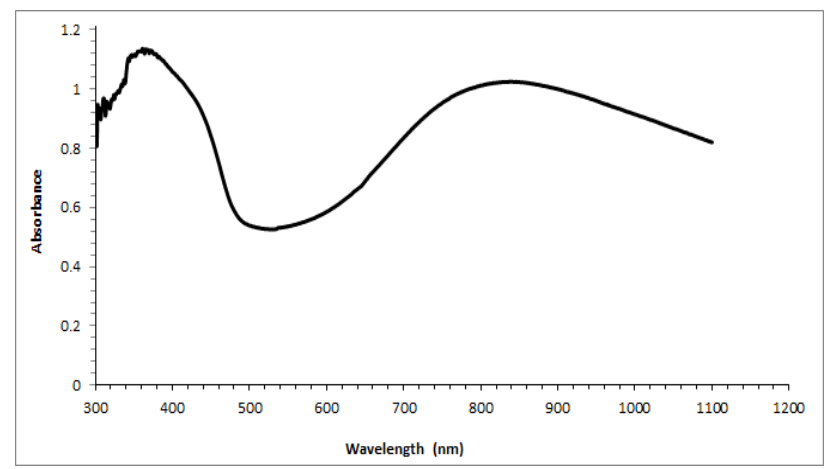

Figure 5. UV-Vis- spectra of PANI.

\section{Electrical Conductivity}

Electrical conductivity is to a great extent dependent on the way of polymer synthesis, purging of the polymer, physical action of the polymer etc. In adding to the environment of the dopants and the method of doping. The conductivity of polyaniline is measured in different capacities by a four-point investigation mechanism and thereafter studied via such equation:

$\sigma=\mathrm{L} /(\mathrm{R} * \mathrm{~S} * \mathrm{~d}) \ldots(5)$

in which the conductivity is calculated from the resistance, $R$, between two sections separated by distance, $L$, having an average area, $S$. wherever $\mathrm{d}$ is the thickness of membranes, $\sigma$ is the conductivity (50). The conductivity of pure PANI appearances metal behavior in which conductivity losses slightly with growing temperature (22), Fig. 6 and 7 show that.

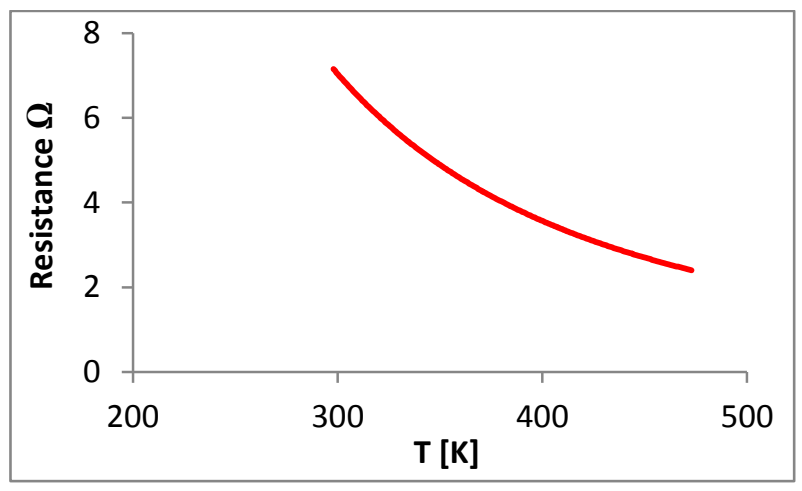

Figure 6. Relational resistances with temperature.

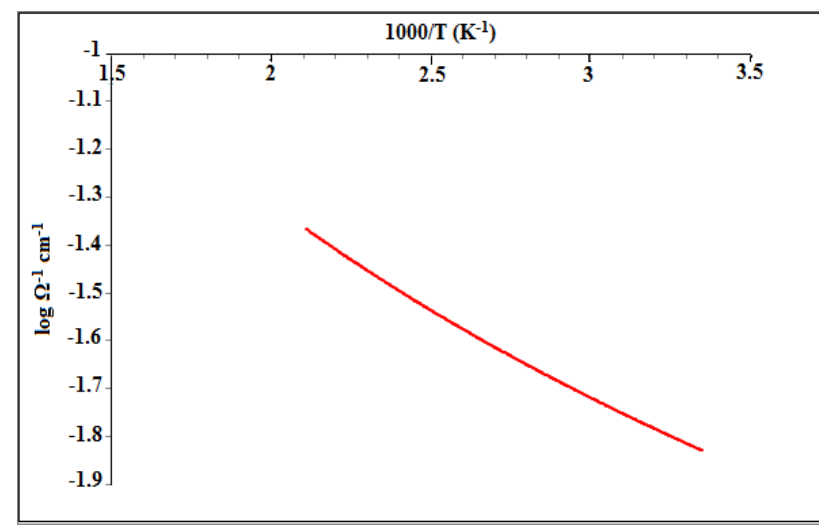

Figure 7.Relational logarithmic conductivity with inverse temperature.

\section{Atomic Force Microscopy (AFM)}

The face morphology of the thin membrane from the polyaniline as seen from the atomic force microscopy (AFM) appear that the grains are uniformly divided into the survey area $(2548.46 \mathrm{~nm}$ $\times 2586.84 \mathrm{~nm}$ ). A first photographic examination from the placed membrane substrate has displayed is compacted and have a good commitment to the substrate. Fig .9 appear 3D and 2D in order to nanostructure of polyaniline. The thin membrane has been placed on ITO substrates through employ electrochemical polymerization (19). The surface roughness average of the polyaniline film is 6.46 $\mathrm{nm}$ and the average particles size is $83.43 \mathrm{~nm}$. These results can be shown in Fig. 8 (a, b). The particle distribution of PANI thin film is shown in Fig. (c) showing a $10 \%$ molecular size $=45.00 \mathrm{~nm}$ and $50 \%$ Diameter $=75.00 \mathrm{~nm}$ and $90 \%$ Diameter $=120.00 \mathrm{~nm}$. 


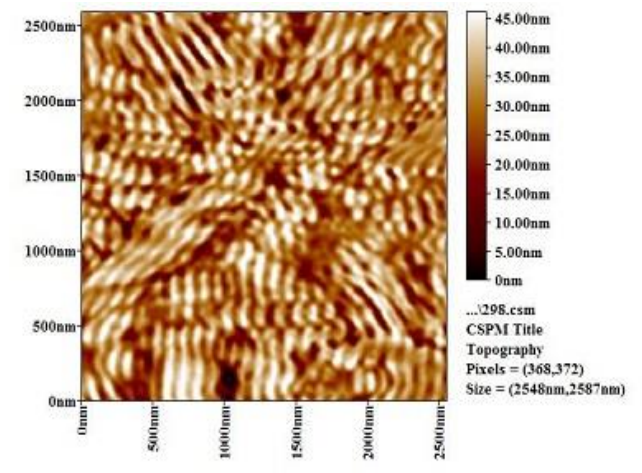

(a)

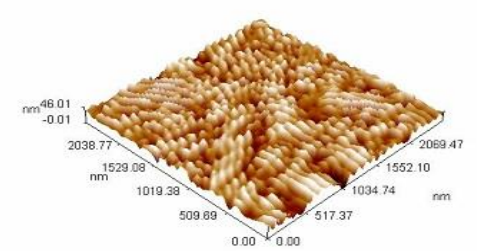

(b)

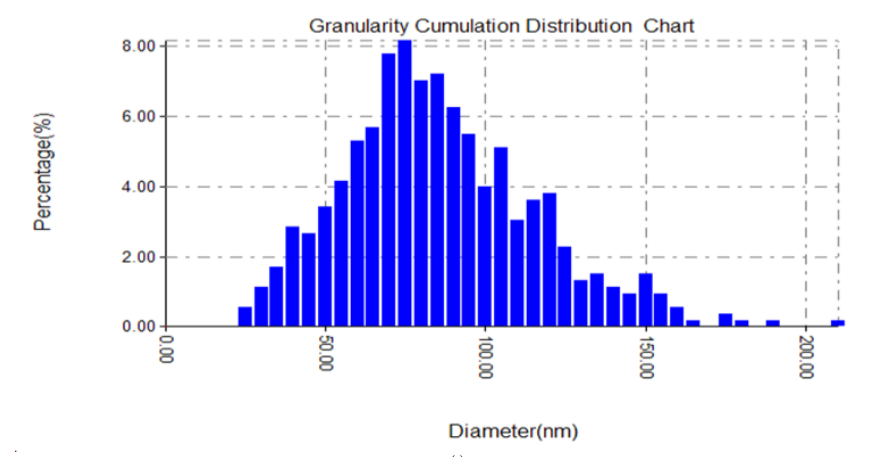

Figure 8. (a, b, c). Atomic force microscopy of PANI and size distribution of PANI. Scanning Electron Microscopy (SEM)

The SEM image of the thin film of PANI is shown in Fig.9. As can be seen from this Figure, the PANI nanoparticles indicate that there is uniform the distribution of the polyaniline nanoparticles, which are spherical in shape in the PANI matrix with few gold clusters of particles (51).

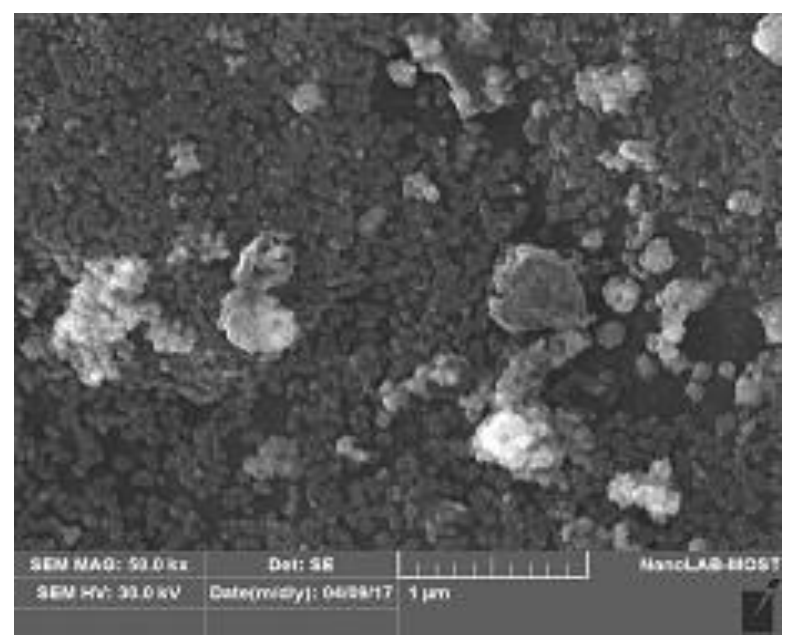

Figure 9. SEM image of PANI thin film.

\section{Conclusion:}

Polyaniline production by electrochemical polymerization produced a nano-thin film using electrolytic middle contained Lithium tetrafluoroborate and acetonitrile, the size of its particles is about $83.43 \mathrm{~nm}$. Noted nanopowder was also produced using acidic solution and its molecular size was $128.43 \mathrm{~nm}$. The samples were examined using FT-IR and RAMAN and compared with the theoretical results found to be approximated. Note that the electrical conductivity is inversely proportional to the opposite temperature. The variety, quantity and sizes of the nanostructures manufactured depend powerfully on the electropolymerization settings such as monomer concentration, scan rate, and the would be.

\section{Acknowledgements}

The authors are thankful to the Department of Physics, College of Science for Women, University of Baghdad for providing required research abilities.

\section{References:}

1. Vivekanandan J, Ponnusamy V, Mahudeswaran A, Vijayanand PS. Synthesis, characterization and conductivity study of polyaniline prepared by chemical oxidative and electrochemical methods. Arch.Appl. Sci. Res. 2011;3(6):147-53.

2. Ninh DH, Thao TT, Long PD, Dinh NN. Characterization of Electrochromic Properties of Polyaniline Thin Films Electropolymerized in H2SO4 Solution. Open J. Org. Polym. Mater. 2016 Jan 7;6(01):30.

3. Sinhary S, Biswas M. Preparation and evaluation of composites from montmorillonite and some heterocyclic polymers: 3. A water dispersible nanocomposite from pyrrole-montmorillonite polymerization system. Mater. Res. Bull. 1999 Oct 


\section{8;34(8):1187-1194.}

4. Bernier P. Conducting Polymers.12th ed. Rodez: Congress on Polymers in French Polymer Group(Eds);1983 September.

5. Glennis S, Franck AJ. Synth Met. 1989;28(681).

6. Grgur BN, Gvozdenović MM, Stevanović J, Jugović BZ, Marinović VM. Polypyrrole as possible electrode materials for the aqueous-based rechargeable zinc batteries. Electrochimica Acta. 2008 May 30;53(14):4627-32.

7. Jones WD, Feher FJ. Comparative reactivities of hydrocarbon carbon-hydrogen bonds with a transition-metal complex. Acc. Chem. Res. 1989 Mar 1;22(3):91-100.

8. Vidal JC, García E, Castillo JR. In situ preparation of a cholesterol biosensor: entrapment of cholesterol oxidase in an overoxidized polypyrrole film electrodeposited in a flow system: Determination of total cholesterol in serum. Analytica Chimica Acta. 1999 Apr 5;385(1-3):213-22.

9. Campbell TE, Hodgson AJ, Wallace GG. Incorporation of erythrocytes into polypyrrole to form the basis of a biosensor to screen for Rhesus (D) blood groups and rhesus (D) antibodies. Electroanalysis. 1999 Apr 1;11(4):215-22.

10. Afrah AH. Studying the effective of conductor polymer substrate on the electrical properties of semiconductors. Baghdad Science Journal. 2017;1:60-67.

11. Chougule MA, Pawar SG, Godse PR, Mulik RN, Sen S, Patil VB. Synthesis and characterization of polypyrrole (PPy) thin films. Soft Nanoscience Letters. 2011 Jan 27;1(01):6.

12. Skotheim TA. Handbook of Conducting Polymers: New York. Marcel Dekker; 1986.

13. Wallace GG, Teasdale PR, Spinks GM, KaneMaguire LA. Conductive electroactive polymers: intelligent polymer systems. CRC press; 2008 Oct 22.

14. Gazard M, Skotheim TA. Handbook of Conducting Polymers: New York. Marcel Dekker; 1986.p.673.

15. Bavane RG. Synthesis and Characterization of thin Films of Conducting Polymers for Gas Sensing Application. SOPS.NMU: Jalgaon;2014 chapter three,Synthesis of polyaniline (PANI); p.22-37.

16. Kanwal F, Siddiqi SA, Tasleem S. Synthesis and characterization of poly aniline/wood and poly aniline/carbon composites. Journal of the Chemical Society of Pakistan. 2009;31(6):882-7.

17. Rami S. Synthesis, Characterization, and Electrochemical Properties of Polyaniline Thin Films. University of South Florida. Graduat theses and dissertations; 2015.

18. Reda SM, Al-Ghannam SM. Synthesis and electrical properties of polyaniline composite with silver nanoparticles. Adv. mater. Phys. Chem. 2012 Jun 20;2(02):75

19. Humud HR, Aubais TK. Nanostructured polyaniline thin films prepared by plasma polymerization at atmospheric pressure. Phys. Sci. Res. Int. 2013 Nov 5;1(4):110-22.

20. Jensen F. Introduction to computational chemistry. John wiley \& sons; $2017 \mathrm{Feb} 6$.

21. Wojciechowski PM, Zierkiewicz W, Michalska D,
Hobza P. Electronic structures, vibrational spectra, and revised assignment of aniline and its radical cation: Theoretical study. J. Chem. Phys. 2003 Jun 22;118(24):10900-11.

22. Piest H, von Helden G, Meijer G. Infrared spectroscopy of jet-cooled neutral and ionized aniline-Ar. J. Chem. Phys. 1999 Jan 22;110(4):20105 .

23. Dotes MF, Sigüenza C, González-Díaz PF. Vibrational study of solid 3, 4-and 2, 6dichloroanilines. Spectrochimica Acta Part A: Molecular Spectroscopy. 1986 Jan 1;42(9):1029-34.

24. Kavitha E, Sundaraganesan N, Sebastian S. Molecular structure, vibrational spectroscopic and HOMO, LUMO studies of 4-nitroaniline by density functional method. Indian Journal of pure and Applied Physics. 2010; 48: 20-30.

25. Faisal M, Khasim S. Electrical conductivity, dielectric behavior and EMI shielding effectiveness of polyaniline-yttrium oxide composites. Bulletin of the Korean Chemical Society. 2013;34(1):99-106.

26. Reda SM, Al-Ghannam SM. Synthesis and electrical properties of polyaniline composite with silver nanoparticles. Advances in materials Physics and Chemistry. 2012 Jun 20;2(02):75.

27. Khairy M, Gouda ME. Electrical and optical properties of nickel ferrite/polyaniline nanocomposite. Journal of advanced research. 2015 Jul 1;6(4):555-62.

28. Boyer MI, Quillard S, Rebourt E, Louarn G, Buisson JP, Monkman A, et al. Vibrational analysis of polyaniline: a model compound approach. J. Phys. Chem. B. 1998 Sep 17;102(38):7382-92.

29. Kang ET, Neoh KG, Tan KL. Polyaniline: a polymer with many interesting intrinsic redox states. Prog. Polym. Sci. 1998 Jan 1;23(2):277-324.

30. Babu VJ, Vempati S, Ramakrishna S. Conducting polyaniline-electrical charge transportation. Materials Sciences and Applications. 2013 Jan 24;4(01):1.

31. Socrates G. Infrared and Raman characteristic group frequencies: tables and charts. John Wiley \& Sons; 2001.

32. Trchova M, Šeděnková I, Konyushenko EN, Stejskal J, Holler P, Ćirić-Marjanović G. Evolution of polyaniline nanotubes: the oxidation of aniline in water. J. Phys. Chem. B. 2006 May 18;110(19):94618.

33. Tang J, Jing X, Wang B, Wang F. Infrared spectra of soluble polyaniline. Synthetic Metals. 1988 May 1;24(3):231-8.

34. Tokarský J, Peikertová P, Kulhánková L, Kutláková KM, Neuwirthová L, Matějka V, et al. Functional nanostructures of montmorillonite with conducting polyaniline. Clay Minerals. 2015 Aug 1;50(3):34151.

35. Grzeszczuk M, Granska A, Szostak R. Raman spectroelectrochemistry of polyaniline synthesized using different electrolytic regimes-multivariate analysis. Int. J. Electrochem. Sci. 2013 Jul 1;8(7):8951-65.

36. Ibrahim KA. Synthesis and characterization of polyaniline and poly (aniline-co-o-nitroaniline) using vibrational spectroscopy. Arabian Journal of 
Chemistry. 2017 May 1;10:S2668-74.

37. Sawant SS, Bhagwat AD, Mahajan CM. Facile Rapid Synthesis of Polyaniline (PANI) Nanofibers. Journal of Nano-and Electronic Physics. 2016;8(1):1037.

38. Arsov LD, Plieth W, Kossmehl G. Electrochemical and Raman spectroscopic study of polyaniline; influence of the potential on the degradation of polyaniline. Journal of Solid State Electrochemistry. 1998 Aug 1;2(5):355-61.

39. Hasoon SA. Electrochemical polymerization and Optical Vibrations of Polyaniline Films, Int J Inn.ovat. Res. Sci. Eng. Technol. 2014;3:9763-9772.

40. Hasoon SA. Electrochemical polymerization, and Raman study of polypyrrole and polyaniline thin films. Int. J. Phys. Sci. 2012;7(38):5468-5476.

41. Wang X, Bernard MC, Deslouis C, Joiret S, Rousseau P. Kinetic reactions in thin polyaniline films revisited through Raman-impedance dynamic coupling. Electrochimica Acta. 2011 Apr 1;56(10):3485-93.

42. Lapin E, Jurevičiūtè I, Niaura G, Malinauskas A, Mažeikienè R. A study of electropolymerization of N, N-dimethylaniline. Synthetic Metals. 2010 Sep 1;160(17-18):1843-7.

43. Bober P, Trchová M, Prokeš J, Varga M, Stejskal J. Polyaniline-silver composites prepared by the oxidation of aniline with silver nitrate in solutions of sulfonic acids. Electrochimica Acta. 2011 Apr $1 ; 56(10): 3580-5$.

44. Mažeikienė R, Malinauskas A, Niaura G. A comparative Raman spectroelectrochemical study of selected polyaniline derivatives in a pH-neutral solution. Synthetic Metals. 2010 May 1;160(910):1060-4.

45. Srinivas CH, Srinivasu D, Kavitha B, Narsimlu N, Kumar KS. Synthesis and characterization of nano size conducting polyaniline. IOSR J Appl Phys. 2012;1(5):12-5.

46. Singh SK, Verma AK, Shuk RK. Synthesis and optical studies of pure polyaniline film. Int J Curr Microbiol App Sci. 2014;3:512-7.

47. Melad O, Alhendawi H, Fayyad M. The Influence of Organic Solvents on the Polymerization of Polyaniline. Journal of Chemistry. 2014;3(4):40-47.

48. Mahalakshmi B, Vedhi C. Synthesis and Characterization of Perfluorooctanoic Acid Anionic Surfactant Doped Nanosize Polyaniline. Open Journal of Synthesis Theory and Applications. 2014 Oct 22;3(04):57.

49. Qin Q, Guo Y. Preparation and characterization of nano-polyaniline film on ITO conductive glass by electrochemical polymerization. Journal of Nanomaterials. 2012 Jan 1;2012:1.

50. Gabal MA, Hussein MA, Hermas AA. Synthesis, Characterization and Electrical Conductivity of Polyaniline-Mn0. 8Zn0. 2Fe2O4 Nano-composites. Int. J. Electrochem. Sci. 2016 Jun 1;11:4526-38.

51. Humud HR, Wasfi AS, Abed MA, Ismaeel ME. Polyaniline/TiO2 nanocomposite thin films prepared by microwave plasma. Wasit Journal for Science \& Medicine. 2015;8(3):143-149.

\section{الخصائص البصرية والكهربائية للتصنيع الكهروكيمياوي لغشاء رقيق من البولي أنيلين
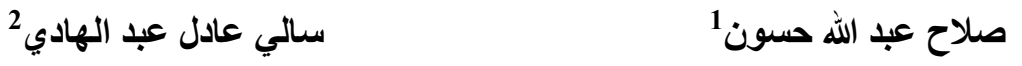

11، قسم الفيزياء، كلية العلوم للبنات، جامعة بغداد، بغداد، العراق

تم انتاج اغشية رقيقة من البولي انيلين باستخدام طريقة التحليل الكهروكيميائي للانيلين في خلية مكونة من فطبين ـ وتم ملاحظة تأثير الشو ائب على لون الاغشية الرقيقة، التي تغيرت من الأزرق إنى إلى اللون الأخضر الدأكن. تم تشخيص PANI بو اسطة تقنيات (Raman)

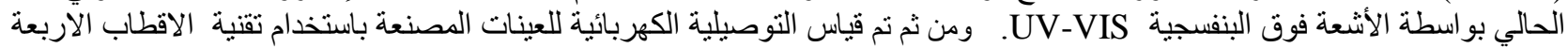

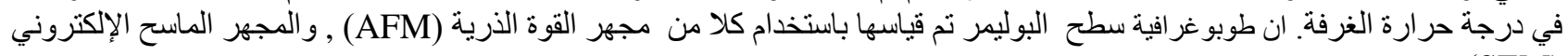

(SEM)

$$
\text { الكلمات المفتاحية : بولي أنيلين، الطرق الكهروكيميائية، XT-IR، در اسة XRD، خصائص الموصلات. }
$$

